MALLOMO: Journal of Community Service

https://jurnal.umsrappang.ac.id/mallomo/index

Vol 1, No 1, Desember 2020, pp 30-34

\title{
Sosialisasi Penyediaan Profil Dan Potensi Desa Pada Website untuk Menunjang Efektifitas Perencanaan Pembangunan Desa
}

\author{
Muhammad Rusdi ${ }^{1}$, Sam Hermansyah ${ }^{2}$ \\ ${ }^{1}$ Ilmu Pemerintahan, Universitas Muhammadiyah Sidenreng Rappang \\ Email: addy.ogy@gmail.com \\ 2 Pendidikan Bahasa Inggrgis, Universitas Muhammadiyah Sidenreng Rappang
}

\section{Keywords:}

Village potential, village website, Development Planning.
Abstract. The governance of Bolu Timoreng Village by utilizing information and communication technology (website management) will create an information technology-based information and communication system. This activity aims to socialize the provision of village profiles and potential through the website. This website is a form of accountability for governance through presenting the profile and potential of the village. So that the government in compiling a better village development plan. This information can be used for various purposes by various parties who need it, especially the profile and potential of the village to be used to prepare development plans. By looking at the village potential website, the government can plan a development plan well and with direction.

Abstrak. Penyelenggaraan pemerintahan Desa Bolu Timoreng dengan memanfaatkan teknologi informasi dan komunikasi (pengelolaan Website) akan menciptakan suatu sistem informasi dan komunikasi berbasis teknologi informasi. Kegiatan ini bertujuan untuk melakukan sosialisasi penyediaan profil dan potensi desa melalui website. Website ini sebagai wujud pertanggungjawaban atas penyelenggaraan pemerintahan melalui penyajian profil dan potensi desa. Sehingga pemerintah dalam menyusun perencanaan pembangunan desa yang lebih baik. Informasi ini dapat digunakan untuk berbagai keperluan oleh berbagai pihak yang membutuhkan terutama profil dan potensi desa digunakan untuk menyusun perencanaan pembangunan. Dengan melihat website potensi desa pemerintah dapat merencanakan sebuah perencanaan pembagunan dengan baik dan terarah.

Coresponden author: Email: addy.ogy@gmail.com

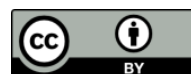

artikel dengan akses terbuka di bawah lisensi CC BY -4.0 
Kata Kunci:

Potensi desa,

website desa,

Perencanaan

Pembangunan.

\section{PENDAHULUAN}

Pada hakekatnya tujuan pembangunan suatu negara dilaksanakan untuk mensejahterakan masyarakat. Untuk mewujudkan tujuan tersebut dilaksanakan pembangunan nasional seutuhnya dan pembangunan masyarakat seluruhnya. Dalam merealisasikan tujuan pembangunan, maka segenap potensi alam harus digali, dikembangkan dan dimafaatkan sebaik- baiknya. Begitu pula dengan Potensi manusia berupa penduduk yang banyak jumlahnya harus ditingkatkan pengetahuan dan keterampilannya sehingga, mampu menggali, mengembangkan dan memanfaatkan potensi alam secara maksimal, dan pelaksanaan program pembangunan tercapai.

Seiring dengan era otonomi daerah, politik pembangunan bergeser dari sentralisasi ke desentralisasi, potensi wilayah semakin dimaksimalkan, seiiring dengan diberlakukannya UndangUndang Nomor 6 Tahun 2014 tentang Desa, Peran Desa/ Wilayah pinggiran semakin diperhatikan untuk dikembangkan, untuk memajukan pembangunan didesa. Maka desa diharapkan mampu mengembangkan potensinya untuk pembangunan dan kesejahteraan masyarakat diwilayahnya. Desa Bulo Timoreng sebagai desa yang senantiasa melakukan pengembangan pembangunan melakukan inovasi dibidang Perencanaan pembangunan yaitu melakukan sosialisasi penyediaan informasi profil dan potensi desa dalam kepentingan untuk efektifitas perencanaan pembanguna. Hal ini tentu merupakan sebuah langkah maju didalam sebuah perencanaan pembangunan.

Peningkatan di berbagai bidang berkenaan pembangunan di desa Bulo Timoreng, dapat berjalan dengan optimal jika perangkat desa memiliki kemampuan mengembangkan Weebsite desa dan menyediankan informasi mengenai profil dan potensi desa, sehinggn dapat berdanpak pada pengembangan sumber daya Aparatur desa yang harus kreatif dan mampu memberikan dampak positif dari adanya potensi desa dengan tujuan akhirnya adalah untuk menyediakan data profil potensi desa dalam penyusunan perencanaan pembangunan untuk kesejahteraan masyarakat. Kreativitas perangkat desa dapat diwujudkan dengan pemanfaatan teknologi informasi melalui website desa. Dengan website desa diharapkan dapat memberikan gambaran tentang Profil dan potensi desa sebagai sarana akuntabilitas kinerja perangkat desa. Website desa juga sangat berperan dalam penyampaian informasi yang lebih mudah dan cepat di akses oleh masyarakat sekitarnya dan Website merupakan media yang sangat tepat untuk mengenalkan kepada masyarakat luas tentang berbagai potensi yang dimiliki suatu desa.

Mengingat tentang pentingnya website desa dimiliki oleh pemerintahan Desa. untuk mengkaji lebih dalam mengenai keuntungan pemanfaatan website oleh Pemerintah Desa, dalam rangka mengenalkan profil dan potensi desa serta sebagai akuntabilitas kinerja perangkat Desa maka dilakukan sosialisasi mengenai pentingnya penyediaan informasi melalui Weebsite desa terutama mengenai prpfi dan potensi desa di desa Bulo Timoreng. untuk penyusunan prencanaan pembangunan di desa, agar perencanaan yang dilakukan dapat efektif dan sesuai dengan kebutuhan dan kepentingan masyarakat. Selain itu juga sebagai sarana informasi mengenai layanan dan prasyarat layanan yang ada dalam Desa.

Perencanaan pembangunan daerah yang bersifat desentralisasi membuka era baru bagi pemeintah desa, dimana dalam sistem Pembangunan Nasional indonesia saat ini mengugunakan dua pendekatan yaitu top douw dan bottom up tujuannya untuk menjamin antara perioritas nasional dengan aspirasi perioritas masyarakat desa. Walupun kenyataannya sebagaian besar daerah belum mengakomodir aspirasi masyarakat desa dikarenakan sebagaian besar program yang diajukan tidak 
dapat diakomodir oleh pemerintah dengan alasan skala prioritas pembangunan dan usulan perencanaan yang tidak akurat.

\section{Metode}

\section{A. Waktu dan Lokasi Pelaksanaan Kegiatan}

Kegiatan sosialisasi ini dilakukan di Kantor Desa Balo Timoreng pada bualan juli dan agustus 2019, kegiatan ini dilakukan dengan mengumpulkan segenap stap dan pemerintah desa Bolu Tomoreng untuk diberikan sosialisasi tentang pentingnya penyediaan [rofil dan potensi desa di Weebsit desa guna kepentingan efektifitas perencanaan pembangunan di desa Bulo Timoreng.

\section{B. Tahapan Kegiatan}

Tahapan kegiatan yang dilakukan dalam kegiatan ini dilakukan dengan cara berikut ini.

1. Menghadirkan para kepala dusun dan stakeholders dalam lingkup pemerintahan desa Bulo Timoreng untuk diberikan sosialisasi mengenai pentingnya Penyediaan Profil dan Potensi desa di Website desa untuk dipergunakan di dalam penyusunan Perencanaan Pembangunan di desa Bulo Timoreng.

2. Melakukan Pelatihan kepada Stap desa untuk pengelolaan Weebsite desa, untuk penyediaan profil dan potensi di Weebsite desa Bulo Timoreng.

3. Melakukan Seminar tentang pentingnya Penyediaan profil dan Potensi desa pada Weebsite desa ektefitas Perencanaan pembangunan di Desa Bulo Timoreng.

\section{Hasil Dan Pembahasan}

Hasil kegiatan ini berupa sosialisasi penyediaan profil dan potensi desa melalui website. Sosialisasi dilakukan melalui seminar yang dihadiri oleh pemerintah desa, masyarakat sekitar, dan dosen pelaksana beserta beberapa mahasiswa. Website desa diharapkan dapat mengefektifkan Perencanaan Pembangunan di Desa Bulo Timoreng. Selain itu, pemerintah desa dan seluruh stakeholdes dapat mengetahui dan memahami tentang manfaat penyediaan profil desa bukan hanya untuk kepentingan perencanaan pembangunan, akan tetapi untuk penyediaan informasi masih bagi masyarakat Desa Bulo Timoreng, dan masyarakat luas lainnya.

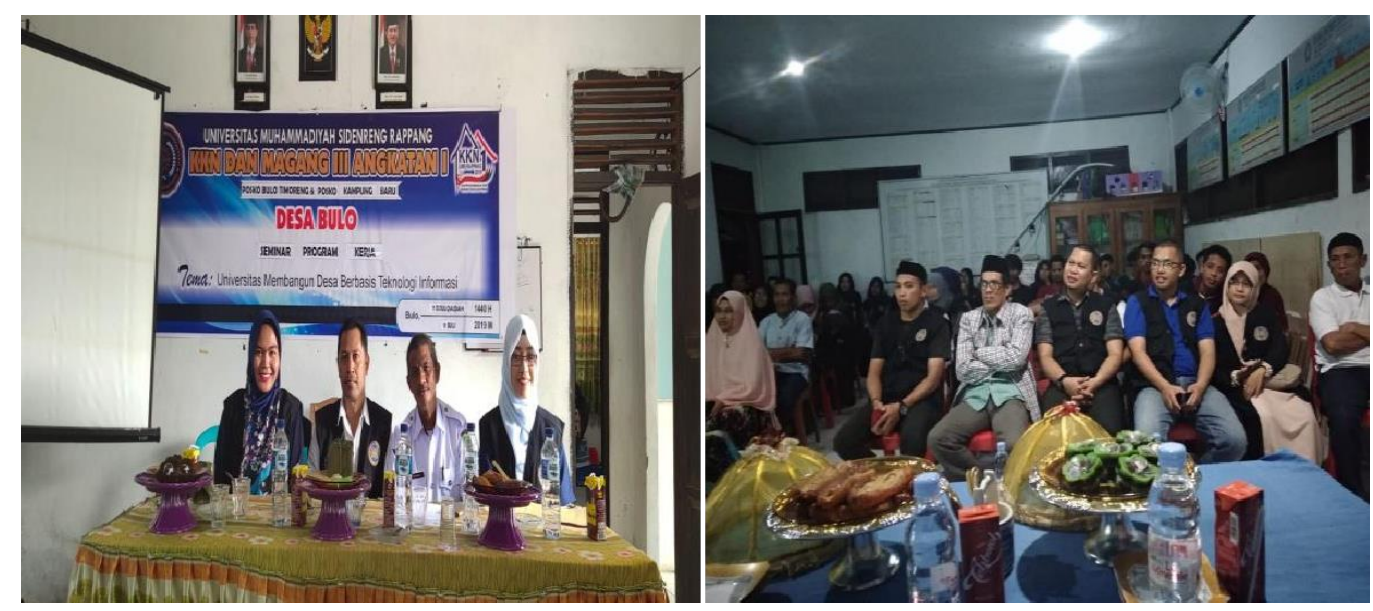

Gambar 1 Dokumentasi kegiatan sosialisasi 
Jadwal pelaksanaan kegiatan dirincikan dalam tabel 1.

Tabel 1 Jadwal Pelaksanaan Kegiatan

\begin{tabular}{|c|c|c|c|c|c|c|c|c|c|c|c|c|c|}
\hline \multirow[t]{2}{*}{ No } & \multirow[t]{2}{*}{ Jenis Kegiatan } & \multicolumn{12}{|c|}{ Bulan } \\
\hline & & 1 & 2 & 3 & 4 & 5 & 6 & 7 & 8 & 9 & 10 & 11 & 12 \\
\hline \multirow[t]{6}{*}{1.} & Persiapan Pengabdian & & & & & & & & & & & & \\
\hline & a. Identifikasi masalah & & & & & & & & & & & & \\
\hline & $\begin{array}{l}\text { b. Diskusi dengan pemerintah } \\
\text { desa }\end{array}$ & & & & & & & & & & & & \\
\hline & c. Kunjungan Ke dusun Cipo & & & & & & & & & & & & \\
\hline & d. Kunjungan ke dusun Taccipi & & & & & & & & & & & & \\
\hline & e. Identifikasi potensi mitra & & & & & & & & & & & & \\
\hline \multirow[t]{4}{*}{2.} & Pelaksanan Pengabdian & & & & & & & & & & & & \\
\hline & a. Sosialisasi tingkat dusun & & & & & & & & & & & & \\
\hline & b. Sosialisasi tingkat desa & & & & & & & & & & & & \\
\hline & $\begin{array}{l}\text { c. Pelaksanaan seminar } \\
\text { Weebsite Desa }\end{array}$ & & & & & & & & & & & & \\
\hline \multirow[t]{4}{*}{3.} & Pasca Pengabdian & & & & & & & & & & & & \\
\hline & a. Pembuatan laporan & & & & & & & & & & & & \\
\hline & b. Pembuatan artikel & & & & & & & & & & & & \\
\hline & c. Pembuatan luaran (HaKI) & & & & & & & & & & & & \\
\hline
\end{tabular}

\section{Simpulan Dan Saran}

Setelah dilakukan seminar sosialisasi Penyediaan Profil dan Potensi Desa pada Weebsite desa untuk mengefektifkan Perencanaan Pembangunan, maka Pemerintah desa dan seluruh stakeholdes dapat mengetahui dan memahami tentang manfaat penyediaan profil desa bukan hanya untuk kepentingan perencanaan Pembangunan, akan tetapi untuk penyediaan informasi masih bagi masyarakat Desa Bulo Timoreng, dan masyarakat luas lainnya.

\section{Daftar Rujukan}

Kasmawi dan Mansur. 2016. Analisa dan Desain Sistem untuk Layanan Informasi Website Desa, SNIT 2016, ISSN : 2303-2790.

Kuncoro, Mudradjad. 2004. Otonomi dan Pembangunan Daerah. Jakarta:

Lewis, Arthur. Development Planning, New York: Harper \& Row.Marbyanto, Edy. Masalah dalam perencanaan (Refleksi singkat untuk kasusperencanaan dan penganggaran di Kaltim) (http//edymarbyanto. blogspt.com) diakses 19 Maret 2016.

Mohammad, Y. 2012. E-Learning Sebagai Media Pembelajaran Interaktif Berbasis Teknologi Informasi. Jurnal IImiah Faristek. Vol. 2, No. 1.

Muzid, S. dan Latifah, N. 2015. Pengembangan sistem layanan informasi desa (SILISA) terintegrasi berbasis SMS gateway, Prosiding SNATIF Ke - 2, ISBN: 978-602-1180-21- 1.

Nurnawati, E.K., Ermawati, dan Ardyrusmaryya, D. 2016. Pemanfaatan basis data terintegrasi pada sistem informasi perangkat bergerak. Prosiding Seminar Nasional Aplikasi Sain \& Teknologi (SNAST), Yogyakarta. ISSN: 1979-911X.

Sulistyowati, F., dan Dibyorin, C.R.. 2013. Partisipasi warga terhadap sistem informasi desa. Jurnal Komunikasi ASPOKOM. Volume 2, Nomor 1, hlm. 579-587. 
34 | MALLOMO: Journal of Community Service

Undang-undang Nomor 25 tahun 2004 tentang Sistem Perencanaan Pembangunan Nasional (SPPN)

Undang-Undang Nomor 23 Tahun 2014 Tentang Pemerintahan Daerah

Undang-Undang Nomor 6 Tahun 2014 tentang Desa 